\title{
Thermal requirements and estimated number of generations of Neopamera bilobata (Say) in strawberry-producing regions of Brazil
}

\author{
Taciana Melissa de Azevedo Kuhn ${ }^{1 *}$ Alci Enimar Loeck ${ }^{1}$ Marcos Botton ${ }^{2}$
}

\begin{abstract}
'Programa de Pós-Graduação em Fitossanidade, Faculdade de Agronomia Eliseu Maciel (FAEM), Universidade Federal de Pelotas (UFPel), 96010-900, Pelotas, RS, Brasil. E-mail: tacianakuhn@hotmail.com. *Corresponding author.

${ }^{2}$ Embrapa Uva e Vinho, Bento Gonçalves, RS, Brasil.
\end{abstract}

\begin{abstract}
The thermal threshold and thermal requirements of Neopamera bilobata were determined, and the number of generations that this species may produce in the main strawberry-producing regions of Brazil was estimated. In a climate chamber $(70 \pm 10 \%$ RH and $12 \mathrm{~h}$ photophase) at 16, 19,22,25,28, or $30 \pm 1^{\circ} \mathrm{C}$, the development of 120 eggs was monitored until the adult stage, at each temperature. Nymphs were maintained in individual cages and fed on strawberry fruits of the cultivar Aromas. The mean duration and viability of the egg and nymph stages were calculated by estimating the lower and upper developmental thresholds and the thermal constant, and this information was used to estimate the number of generations per year in different strawberry-producing regions of Brazil. The egg-to-adult duration decreased as temperatures increased, up to $28^{\circ} \mathrm{C}\left(93.4,83.2,43.9\right.$, and 31.4 days at $19,22,25$, and $28^{\circ} \mathrm{C}$, respectively). Viability of nymphs was highest between 22 and $28^{\circ} \mathrm{C}$. At $30^{\circ} \mathrm{C}$, the egg-to-adult duration increased (36 days), while the viability decreased (11.11\%). The lower egg-to-adult developmental threshold was $15.2^{\circ} \mathrm{C}$ and the thermal constant was 418.4 degree-days. Calculating the number of generations indicated that the largest number (5.1 generations yr ${ }^{-1}$ ) was obtained for the municipality of Jaboti, Paraná, and the smallest for Caxias do Sul, Rio Grande do Sul (1.9 generations yr $\left.{ }^{-1}\right)$. Our findings demonstrated that important strawberry-producing regions in Brazil are suitable for the development of $N$. bilobata.

Key words: environmental factors, thermal requirements, predictive models.
\end{abstract}

Exigências térmicas e estimativa do número de gerações de Neopamera bilobata (Say) em regiões produtoras de morango do Brasil

RESUMO: A temperatura base e as exigências térmicas de Neopamera bilobata foram determinadas sendo estimado o número de gerações que a espécie realiza nas principais regiões produtoras de morango no Brasil. Em uma câmara climatizada (UR $70 \pm 10 \%$ e fotofase de $12 \mathrm{~h}$ ) nas temperaturas de $16,19,22,25,28$ ou $30 \pm 1{ }^{\circ} \mathrm{C}$, o desenvolvimento de 120 ovos por temperatura foi monitorado até a fase adulta. As ninfas foram individualmente mantidas em gaiolas alimentando-as com frutos de morangueiro da cultivar Aromas. A duração média e a viabilidade da fase de ovo e de ninfa foi calculada estimando-se os valores de temperatura base inferior, temperatura base superior, constante térmica e número provável de gerações anuais que o percevejo completa em diferentes regiões produtoras de morangueiro do Brasil. A duração do desenvolvimento ovo-adulto de $N$. bilobata diminui com a elevação da temperatura até $28^{\circ} \mathrm{C}$ (93,4; 83,2; 43,9 e 31,4 dias para 19, 22, 25 e $28^{\circ} \mathrm{C}$, respectivamente) apresentando maior viabilidade da fase de ninfa entre 22 a $28^{\circ} \mathrm{C}$. A $30^{\circ} \mathrm{C}$, a duração da fase ovo-adulto aumentou (36 dias), enquanto a viabilidade diminuiu $(11,11 \%)$. A temperatura base inferior para o desenvolvimento ovo-adulto foi de $15,2{ }^{\circ} \mathrm{C}$ e a constante térmica de 418,4 graus dia. O maior número de gerações (5,1 gerações/ano) foi obtido para a cidade de Jaboti, PR, e o menor para Caxias do Sul, RS (1,9 gerações/ano). Os valores estimados demonstram que as regiões de importância na produção do morangueiro no Brasil são aptas ao desenvolvimento de N. bilobata.

Palavras-chave: Fatores ambientais, exigências térmicas, modelo de previsão.

\section{INTRODUCTION}

Most poikilothermic species are adapted to different temperature ranges, as temperature is a major factor influencing their geographic distributions (TRUDGILL et al., 2005). Thus, knowledge of the thermal requirements of a species is essential to predict its potential establishment in a given region (JAROŠÍK et al., 2015).

The effect of temperature on the dispersal and infestation intensity of a pest may affected by the physiological state of the insect or its host. By influencing natural mortality, changing plant-herbivore interactions, limiting the range of 
host plants, or altering their physiology, extreme temperatures restrict the size and geographical distribution of pest populations (BALE et al., 2002; KIRITANI, 2007; SPEIGHT et al., 2008; WHALEN \& HARMON, 2015). Thus, understanding the effects of climate variation on insects is essential to predict the activity and density of insect pests or disease vectors (SPEIGHT et al., 2008). One example is Jadera haematoloma (HerrichSchaeffer) (Heteroptera: Rhopalidae). This species is found in subtropical regions of the United States; since the 1980s, it has extended its range northward in response to milder temperatures and adaptation to different host plants (HOFFMAN \& STEINER JR, 2005). For Umbonia crassicornis (Amyot \& Serville) (Hemiptera: Membracidae), regular periods of below-freezing temperatures in northern Florida have been an effective barrier to prevent it from dispersing to this region (DOWELL \& WOOD, 2014).

The direct influence of temperature on insect development can be measured by determining the thermal threshold and thermal constant. These parameters enable the development of predictive models for the occurrence of these insects (SILVEIRA NETO, 1976; SPEIGHT et al., 2008), such as those for the species Lygus hesperus Knight, L. rugulipennis Poppius, and $L$. lineolaris Palisot (Hemiptera: Miridae), pests of strawberries in the United States, United Kingdom, and Canada, respectively (BOSTANIAN et al., 1990; XU et al., 2014; UCDAVIS, 2015).

In Brazil, species of the genus Lygus do not cause yield losses in strawberry crops. However, the seed bug Neopamera bilobata (Say) (Hemiptera: Rhyparochromidae) has been recently reported in southern Brazil, feeding on unripe and ripe strawberry fruits and causing growth stunting, hardening, drying, and brown discoloration of pseudo fruits in early stages of infestation (BOTTON, 2016). These symptoms were described by BROOKS et al. (1929), who also noted that when infestation levels are high, the plant crown is also attacked, resulting in wilting.

To understand how populations of insects occur, several biological and abiotic factors must be evaluated, including the influence of temperature. For $N$. bilobata there is no information about the effect of this factor on development and population growth. This study was conducted to determine the thermal threshold and thermal requirements of $N$. bilobata and to estimate the number of generations of this species in the main strawberry-producing regions of Brazil.

\section{MATERIALS AND METHODS}

The assay was conducted in the Laboratory of Entomology of Embrapa Uva e Vinho in Bento Gonçalves, Rio Grande do Sul, in a climate chamber (B.O.D.) with $70 \pm 10 \%$ relative humidity and $12 \mathrm{~h}$ photophase.

\section{Fruit materials}

Strawberry fruits of the cultivar Aromas were harvested from plants grown in pots filled with 3L of soil, fertilized as recommended for the crop by CQFSRS/SC (2004), in a greenhouse.

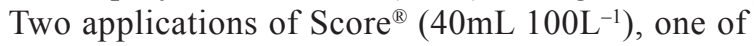
Vertimec $18 \mathrm{EC}^{\circledR}\left(50 \mathrm{~mL} 100 \mathrm{~L}^{-1}\right)$ and one of Karate Zeon $50 \mathrm{CS}^{\circledR}\left(80 \mathrm{~mL} 100 \mathrm{~L}^{-1}\right)$ were performed as phytosanitation treatments during the experiment, for the control of Mycosphaerella fragariae (Tul.) Lindau, Tetranychus urticae Koch and Chaetosiphon fragaefolii (Cockerell), respectively. Fruits were only used in the experiments after a minimum period of 30 or 15 days after the application of acaricides/insecticides or fungicides, respectively. A 10\% milk solution was also applied weekly to control powdery mildew Sphaerotheca macularis (Wallr. ex Fr.) Jacz. f. sp. fragariae (EMBRAPA, 2006).

\section{Insect origin}

Insects used to start the laboratory colony were collected from strawberries 'Albion', in Caxias do Sul (29 $19^{\circ}$ ' 49'S and $\left.050^{\circ} 57^{\prime} 10^{\prime \prime} \mathrm{W}\right)$, and of strawberries 'Aromas', in Farroupilha $\left(29^{\circ} 08^{\prime} 15^{\prime \prime} \mathrm{S}\right.$ and $051^{\circ} 24^{\prime} 30^{\prime \prime}$ W), Rio Grande do Sul.

Adult specimens were identified by Dr. Pablo Matías Dellapé (National University of La Plata), who identified the target species as $N$. bilobata. Voucher specimens were deposited in the Padre Jesus Santiago Moure Museum (Universidade Federal do Paraná, Curitiba, Paraná) and in the Entomological Collection of Embrapa Uva e Vinho.

A colony was established at $25 \pm 1^{\circ} \mathrm{C}$, $12 \mathrm{~h}$ photophase, as described by KUHN et al. (2014). Adults were maintained in 1L clear plastic containers $(\varnothing 12 \mathrm{~cm} \times 9.5 \mathrm{~cm}$ high $)$, covered with perforated lids $(4 \times 4 \mathrm{~cm})$ lined with voile fabric. For nymphs, the lid was replaced with plastic wrap. The bottom of the container was lined with paper towels to prevent excess moisture. Two ripe strawberry fruits of the cultivar Aromas were provided as food per container, and replaced twice a week. 


\section{Experimental design and data analysis}

Ripe fruits of the cultivar Aromas were placed in containers with adult insects from the laboratory colony and examined after $24 \mathrm{~h}$ for eggs, which were removed with the aid of a moistened brush. Eggs of known age were then transferred to unripe strawberry fruits, which were placed in individual $80 \mathrm{ml}$ cylindrical plastic containers $(\varnothing$ $=5 \mathrm{~cm} \times 6 \mathrm{~cm}$ high) with two perforations on the lid (each $1.5 \mathrm{~cm}$ in diameter), sealed with voile fabric attached with vinyl cement.

Six temperatures were examined $(16,19$, $22,25,28$, or $30 \pm 1^{\circ} \mathrm{C}$ ) and for each temperature, 120 eggs were used. A replicate consisted of one fruit and one egg. During development, nymphs were fed with unripe strawberry fruits (replaced twice a week) harvested from the greenhouse planting described above.

The development from egg to adult emergence was monitored daily. The mean durations and viabilities of the egg and nymph stages were calculated, and the duration values were compared with the Tukey test $(\mathrm{P}<0.05)$. Based on the duration of each development stage, the estimated lower developmental threshold (Tl) and the thermal constant $(\mathrm{K})$ were determined with the Hyperbole method (HADDAD et al., 1999), from the equation of Réaumur:

$\mathrm{K}=\mathrm{D}(\mathrm{T}-\mathrm{Tl})$

$\mathrm{K}=$ Thermal constant; $\mathrm{D}=$ Development time (days); $\mathrm{T}=$ Temperature at which the insect grew; $\mathrm{Tl}=$ lower developmental threshold

Therefore: $1 / \mathrm{D}=-\mathrm{Tl} / \mathrm{K}+(1 / \mathrm{K}) \cdot \mathrm{T}$

Thus: $\mathrm{Y}=1 / \mathrm{D} ; \mathrm{a}=-\mathrm{Tl} / \mathrm{K} ; \mathrm{b}=1 / \mathrm{K} ; \mathrm{x}=\mathrm{T}$

Obtaining the equation: $\mathrm{Y}=\mathrm{a}+\mathrm{b} . \mathrm{x}$

As by definition the insect stops developing at the lower developmental threshold $(\mathrm{Y}=0): \mathrm{Tl}=-\mathrm{a} / \mathrm{b}{ }^{\circ} \mathrm{C}$ and $\mathrm{K}=1 / \mathrm{b}$ DD (degreedays). To calculate the upper developmental threshold (Tu) (SILVEIRA NETO et al., 1976) the equation is: $\mathrm{Tu}=\mathrm{Tl}+\sqrt{\mathrm{K}}$.

The number of generations (NG) of $N$. bilobata per year was estimated based on the calculated $\mathrm{Tl}$ and $\mathrm{K}$ and historical monthly mean temperatures, where:

Cumulative degree-days $=\Sigma_{(\text {Jan-Dec })} \mathrm{N}(\mathrm{Tm}-\mathrm{Tl})$

$\mathrm{NG}=$ Cumulative degree-days $/ \mathrm{K}$

$\mathrm{N}=$ number of days in the month, $\mathrm{Tm}=$ mean monthly temperature for each location, $\mathrm{Tl}=$ lower developmental threshold and $\mathrm{K}=$ thermal constant. Months with a lower mean monthly temperature than the lower developmental threshold were not included in the calculation of the cumulative degree-days.
Temperature data were selected from eight municipalities: Caxias do Sul (RS), Pelotas (RS), Jaboti (PR), São José dos Pinhais (PR), Atibaia (SP), Piedade (SP), Datas (MG), and Pouso Alegre (MG) (Brazilian state abbreviations: MG, Minas Gerais; PR, Paraná; RS, Rio Grande do Sul; SP, São Paulo).

These municipalities were chosen because they are large strawberry producers in their regions (CARVALHO et al., 2014), and also because they have contrasting temperatures within the same region. For the municipalities of São José dos Pinhais, Jaboti, Datas, and Pouso Alegre, data from Curitiba, Joaquim Tavora, Diamantina, and Itajubá respectively were used, as they have similar climate conditions monitored by local meteorological stations. The mean monthly temperatures used were obtained from the Universidade Federal de Itajubá - UNIFEI (data used for Pouso Alegre), from the Center of Integrated Agrometereological Information CIIAGRO (for the municipalities of Atibaia and Piedade), Instituto de Agronomia do Paraná IAPAR (for the municipality of Jaboti), and from the Insituto Nacional de Meteorologia (INMET) for the others.

\section{RESULTS AND DISCUSSION}

$N$. bilobata did not complete its development at $16^{\circ} \mathrm{C}$; only one individual reached the fourth instar (Table 1). The development time was longest at $19^{\circ} \mathrm{C}$, with the second-lowest viability from egg to adult, indicating that this temperature is not suitable for growth of this species (Table 1).

The mean duration of the developmental stages of $N$. bilobata decreased as temperatures increased up to $28^{\circ} \mathrm{C}$, while nymphal viability increased between 22 and $28^{\circ} \mathrm{C}$ (Table 1). These results support field observations reported by WILSON (1938), who described high infestations of $N$. bilobata in warmer periods. Field observations by GALLARDO-GRANADOS et al. (2016) in a protected crop area and open environment documented a population increase at the beginning of spring, favored by temperatures above $20^{\circ} \mathrm{C}$.

At $30^{\circ} \mathrm{C}$, the maximum temperature studied here, the development cycle lengthened, indicating that at this temperature, development may be compromised, as well as viability $(11.11 \%)$, which was the lowest for the temperatures tested (Table 1). 
Table 1 - Duration (mean \pm SD) (days) and viability (\%) of the egg and nymphal stages and the development cycle (egg-adult) of Neopamera bilobata fed unripe strawberry fruits of the cultivar Aromas at the temperatures of $16,19,22,25,28$, or $30 \pm 1{ }^{\circ} \mathrm{C}$ $(70 \pm 10 \% \mathrm{RH} ; 12 \mathrm{~h}$ photophase)

\begin{tabular}{|c|c|c|c|c|c|c|c|c|}
\hline \multirow{2}{*}{$\begin{array}{l}\mathrm{T} \\
{ }^{\circ} \mathrm{C}\end{array}$} & \multirow{2}{*}{ Parameter } & \multicolumn{6}{|c|}{ 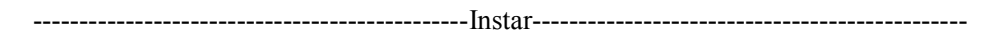 } & \multirow{2}{*}{$\begin{array}{l}\text { Developmen } \\
\text { Cycle } \\
\text { (egg-adult) }\end{array}$} \\
\hline & & Egg & $1^{\text {st }}$ & $2^{\text {nd }}$ & $3^{\text {rd }}$ & $4^{\text {th }}$ & $5^{\text {th }}$ & \\
\hline \multirow{3}{*}{16} & Duration (days) & $33.3 \pm 2.4 \mathrm{a}$ & $34.6 \pm 8.8 \mathrm{a}$ & $20.0 \mathrm{a}$ & $25.0 \mathrm{a}$ & - & - & - \\
\hline & Viability (\%) & 75.9 & 9.8 & 12.5 & 100.0 & 0 & 0 & 0 \\
\hline & $\mathrm{n}^{1}$ & $(82)$ & $(8)$ & $(1)$ & $(1)$ & - & - & - \\
\hline \multirow{3}{*}{19} & Duration (days) & $19.9 \pm 1.7 \mathrm{~b}$ & $19.2 \pm 5.1 \mathrm{~b}$ & $15.0 \pm 6.3 \mathrm{a}$ & $16.2 \pm 9.5 \mathrm{ab}$ & $12.2 \pm 3.8 \mathrm{a}$ & $15.4 \pm 2.3 \mathrm{a}$ & $93.4 \pm 17.0 \mathrm{a}$ \\
\hline & Viability (\%) & 67.0 & 61.5 & 77.5 & 77.4 & 83.3 & 95.0 & 19.6 \\
\hline & $\mathrm{n}$ & $(65)$ & $(40)$ & $(31)$ & (24) & (20) & (19) & (19) \\
\hline \multirow{3}{*}{22} & Duration (days) & $16.8 \pm 1.4 \mathrm{c}$ & $15.6 \pm 4.3 \mathrm{c}$ & $14.6 \pm 5.5 \mathrm{a}$ & $14.0 \pm 8.7 \mathrm{bc}$ & $11.3 \pm 3.7 \mathrm{a}$ & $14.0 \pm 3.0 \mathrm{a}$ & $83.2 \pm 17.7 \mathrm{~b}$ \\
\hline & Viability (\%) & 74.3 & 66.7 & 80 & 72.5 & 89.6 & 100.0 & 25.7 \\
\hline & $\mathrm{n}$ & (75) & $(50)$ & $(40)$ & (29) & (26) & (26) & (26) \\
\hline \multirow{3}{*}{25} & Duration (days) & $11.1 \pm 1.7 \mathrm{~d}$ & $8.2 \pm 1.9 \mathrm{~d}$ & $6.7 \pm 2.9 \mathrm{~b}$ & $5.1 \pm 2.8 \mathrm{~cd}$ & $5.7 \pm 2.3 \mathrm{~b}$ & $7.5 \pm 2.5 \mathrm{~b}$ & $43.9 \pm 8.6 \mathrm{c}$ \\
\hline & Viability (\%) & 74.1 & 70 & 96.4 & 98.1 & 98.1 & 98.1 & 47.2 \\
\hline & $\mathrm{n}$ & $(80)$ & (56) & (54) & (53) & (52) & (51) & (51) \\
\hline \multirow{3}{*}{28} & Duration (days) & $7.8 \pm 0.5 \mathrm{e}$ & $6.1 \pm 1.3 \mathrm{~d}$ & $4.3 \pm 2.2 \mathrm{~b}$ & $4.2 \pm 2.0 \mathrm{~d}$ & $4.5 \pm 2.4 \mathrm{~b}$ & $5.5 \pm 1.9 \mathrm{c}$ & $31.4 \pm 5.9 \mathrm{~d}$ \\
\hline & Viability (\%) & 92.5 & 86.8 & 79.1 & 83.8 & 96.5 & 89.1 & 45.8 \\
\hline & $\mathrm{n}$ & (99) & (86) & (68) & (57) & (55) & (49) & (49) \\
\hline \multirow{3}{*}{30} & Duration (days) & $7.1 \pm 0.3 \mathrm{f}$ & $5.9 \pm 1.1 \mathrm{~d}$ & $5.5 \pm 1.4 \mathrm{~b}$ & $5.9 \pm 1.6 \mathrm{~cd}$ & $5.7 \pm 1.8 \mathrm{~b}$ & $7.1 \pm 2.5 b c$ & $36.0 \pm 6.5 \mathrm{~cd}$ \\
\hline & Viability (\%) & 57.3 & 56.7 & 81.6 & 77.4 & 83.3 & 65 & 11.1 \\
\hline & $\mathrm{n}$ & $(67)$ & $(38)$ & (31) & (24) & $(20)$ & (13) & (13) \\
\hline
\end{tabular}

${ }^{1} \mathrm{n}=$ number of observations. ${ }^{*}$ Means followed by the same letters within a column are not significantly different at $\mathrm{P}<0.05$ (Tukey test).

The lowest $\mathrm{Tl}$ for the stages of $N$. bilobata was observed for the egg stage $\left(13.1^{\circ} \mathrm{C}\right)$ and 121.8 degree-days were needed for the insect to complete this stage (Figure 1, table 2). The $\mathrm{K}$ values for $N$. bilobata instars ranged from 50.6 ( $2^{\text {nd }}$ instar) and 80.6 ( $1^{\text {st }}$ instar $)$ degree-days, and 418.4 degree-days for the complete development (Table 2). Since this is the first study to determine the thermal requirements of $N$. bilobata, no comparative information is available. The $\mathrm{K}$ value obtained in our study was similar to the 140 and 346 degree-days reported by PICKEL et al. (1990) for the development of L. hesperus eggs and egg to adult, respectively; this species is a member of the same order, and causes damage to strawberry production in the United States.

The $\mathrm{Tl}$ observed for egg-to-adult development was $15.2^{\circ} \mathrm{C}$ (Table 2) and the upper threshold temperature (Tu) was $35.6^{\circ} \mathrm{C}$, a thermal amplitude that matches with the cold and mild climates of the strawberry-producing regions in the country (CARVALHO et al., 2014).

Using the $\mathrm{Tl}$ and the thermal constant needed to complete the stages from egg to adult, the number of generations per year was estimated for the main strawberry-producing regions of Brazil (Figure 2). The highest number of generations was obtained for the municipality of Jaboti, Paraná, with 5.1 generations/year, as opposed to Caxias do Sul, Rio Grande do Sul, with only 1.9 generations/year. These values demonstrate that most of the important strawberry-producing regions are suitable for the development of several generations of $N$. bilobata.

The estimated number of generations in the different strawberry-producing regions indicates where $N$. bilobata has the highest potential for population growth. Daily or weekly climate data in the different localities are useful for studies on predicting the occurrence and monitoring of pests. According to Integrated Pest Management (IPM) recommendations, the cultivation of any crop based on these concepts allows a rational use of resources and promotes economic and environmental sustainability (NORRIS et al., 2003). This approach can be used for the control of $N$. bilobata in Brazil, since similar strategies have been implemented elsewhere, such as for L. hesperus in strawberries in the United States (UCDAVIS, 2015). 


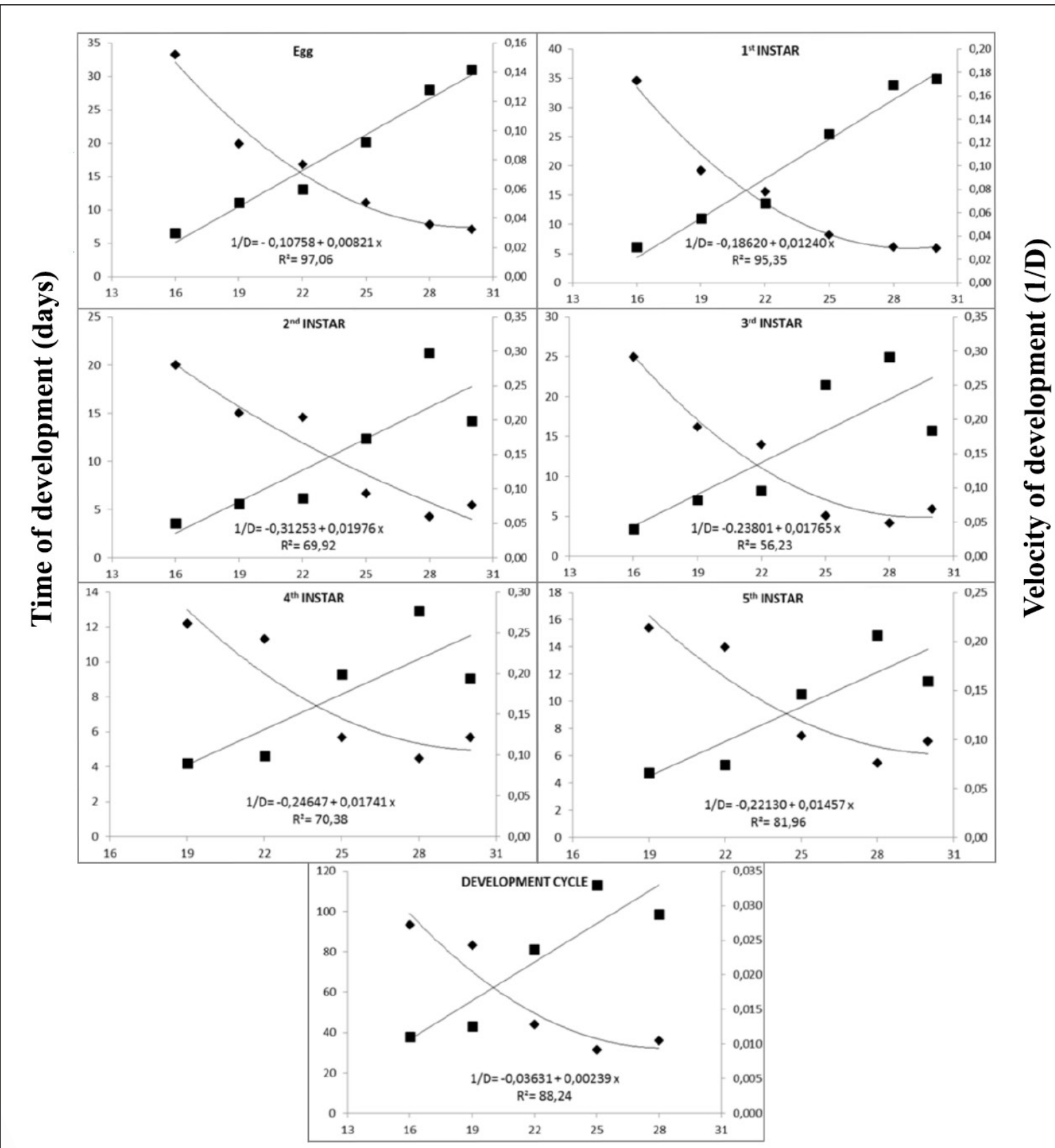

Temperature $\left({ }^{\circ} \mathrm{C}\right)$

Figure 1 - Relationship between temperature, development time $(\diamond)$ and velocity of development $(\mathbf{-})$ for egg and nymphal $\left(1^{\text {st }}, 2^{\text {nd }}\right.$, $3^{\text {rd }}, 4^{\text {th }}$, and $5^{\text {th }}$ instar) stages and development cycle (egg-adult) of Neopamera bilobata fed unripe strawberry fruits of the cultivar Aromas at the temperatures of $16,19,22,25,28$, or $30 \pm 1{ }^{\circ} \mathrm{C}(70 \pm 10 \% \mathrm{RH} ; 12 \mathrm{~h}$ photophase). 
Table 2 - Lower threshold temperature (Tl), thermal constant $(\mathrm{K})$ in degree-days, linear equation for the development velocity (1/D) and coefficient of determination $\left(\mathrm{R}^{2}\right)$ of the egg and nymph stages $\left(1^{\text {st }}, 2^{\text {nd }}, 3^{\text {rd }}, 4^{\text {th }}\right.$, and $5^{\text {th }}$ instar), and total development (egg-adult) of Neopamera bilobata fed unripe strawberry fruits of the cultivar Aromas at 16, 19, 22, 25, 28, or $30 \pm 1{ }^{\circ} \mathrm{C}(70 \pm 10 \% \mathrm{RH} ; 12 \mathrm{~h}$ photophase).

\begin{tabular}{lcccccc}
\hline Stage & $\mathrm{Tl}\left({ }^{\circ} \mathrm{C}\right)$ & $\mathrm{K}$ & Regression Equation & $\mathrm{R}^{2}$ & $\mathrm{~F}$ \\
\hline Egg & 13.1 & 121.8 & $1 / \mathrm{D}=-0.10758+0.00821 \times$ & 97.06 & 11715.16 & $<0.0001$ \\
1st Instar & 15.0 & 80.6 & $1 / \mathrm{D}=-0.18620+0.01240 \times$ & 95.35 & 1028.82 & $<0.0001$ \\
2nd Instar & 15.8 & 50.6 & $1 / \mathrm{D}=-0.31253+0.01976 \times$ & 69.92 & 115.97 & $<0.0001$ \\
\hline 3rd Instar & 13.5 & 56.7 & $1 / \mathrm{D}=-0.23801+0.01765 \times$ & 56.23 & 68.12 & $<0.0001$ \\
4th Instar & 14.2 & 57.4 & $1 / \mathrm{D}=-0.24647+0.01741 \times$ & 70.38 & 79.90 & $<0.0001$ \\
5th Instar & 15.2 & 68.6 & $1 / \mathrm{D}=-0.22130+0.01457 \times$ & 81.96 & 118.58 & $<0.0001$ \\
Total development (egg-adult) & 15.2 & 418.4 & $1 / \mathrm{D}=-0.03631+0.00239 \times$ & 88.24 & 433.12 & $<0.0001$ \\
\hline
\end{tabular}

A

\section{Cumulative degree-days (DD)}

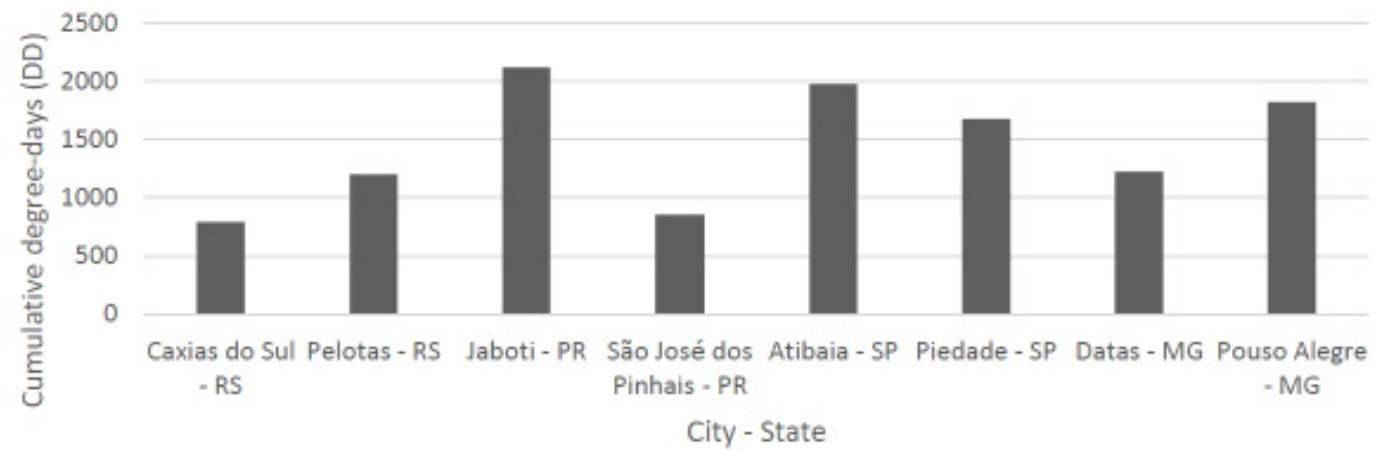

B

\section{Estimated number of generations / year}

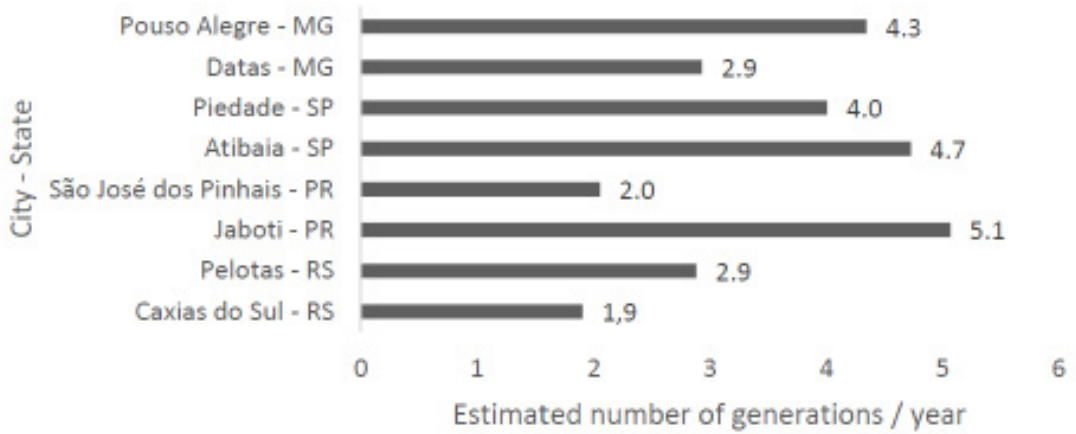

Figure 2 - Cumulative degree-days (DD) (A) and estimated number of generations (B) of Neopamera bilobata per year in strawberry-producing municipalities ${ }^{1}$ in Brazil, based on mean annual temperatures $\left({ }^{\circ} \mathrm{C}\right)$ and annual cumulative degree-days (Tl value used was 15.19 and $\mathrm{K}$ of 418.41). Brazilian state abbreviations: MG, Minas Gerais; PR, Paraná; RS, Rio Grande do Sul; SP, São Paulo. ${ }^{1}$ For the municipalities of São José dos Pinhais, Jaboti, Datas, and Pouso Alegre, data for Curitiba, Joaquim Távora, Diamantina, and Itajubá were used, respectively, as they have similar climate conditions monitored by local weather stations. 


\section{CONCLUSION}

The threshold temperature and thermal requirements of the seed bug Neopamera bilobata fed on strawberries are $15.2^{\circ} \mathrm{C}$ and $418.4 \mathrm{DD}$, respectively. $N$. bilobata can produce more than one generation annually, and is adapted to all Brazilian strawberry-producing regions.

\section{ACKNOWLEDGMENTS}

We thank Dr. Pablo Matías Dellapé for insect identification, César Iván Suárez Castellanos for aid in data analysis, and Coordenação de Aperfeiçoamento de Pessoal de Nível Superior (CAPES), Conselho Nacional de Desenvolvimento Científico e Tecnológico (CNPq), Universidade Federal de Pelotas (UFPel) and Embrapa for financial support

\section{REFERENCES}

BALE, J. S. et al. Herbivory in global climate change research: direct effects of rising temperature on insect herbivores. Global Change Biology, v. 8, p. 1-16, 2002. Available from: <http://dx.doi.org/10 .1046/j.1365-2486.2002.00451.x>. Accessed: Jun. 27, 2016. doi: 10.1046/j.1365-2486.2002.00451.x.

BROOKS, A. N. et al. Strawberries in Florida: culture, diseases and insects. Florida: University of Florida Agricultural Experiment Station, 1929. 523p. (Bulletin 204).

BOSTANIAN, N. J. et al. Seasonal fluctuations of Lygus lineolaris (Palisot de Beauvois) (Hemiptera: Miridae) nymphal populations in strawberry fields. Agriculture, Ecosystems and Environment, v. 30, p. 327-336, 1990. Available from: <http://dx.doi.org/10.1016/01678809(90)90114-S>. Accessed: Jun. 27, 2016. doi: 10.1016/01678809(90)90114-S.

BOTTON, M. et al. Bioecologia e Caracterização de danos de Neopamera bilobata (Say, 1832) (Hemiptera: Rhyparochromidae) em morangueiro. Bento Gonçalves: Embrapa-CNPUV, 2016. 10p. (Embrapa-CNPUV. Comunicado Técnico 194)

CARVALHO, S. P. et al. O cultivo do morangueiro no Brasil. In: ZAWADNEAK, M. C. A.; SCHUBER, J. M.; MÓGOR, A. F. Como produzir morango. Curitiba, Editora UFPR, 2014. Cap. 1, p. 15-31.

COMISSÃO DE QUÍMICA E FERTILIDADE DO SOLO CQFSRS/SC. Manual de adubação e calagem para os estados do Rio Grande do Sul e de Santa Catarina. 10 ed. Porto Alegre: SBCS - Núcleo Regional Sul/UFRGS, 2004. 400p.

DOWELL, R. V.; WOOD, T. K. Influence of freezing temperatures on the distribution of Umbonia crassicornis (Hemiptera: Membracidae) in Florida. Florida Entomologist, v. 97, n. 1, p. 317-319, 2014. Available from: $<$ http://dx.doi.org/10.1653/024.097.0150>. Accessed: Jun. 27, 2016. doi: 10.1653/024.097.0150.

EMBRAPA - Clinica Fitossanitária Embrapa Clima Temperado. Oídio em morangueiro. Pelotas: Embrapa Clima Temperado, 2006. 2p.

GALLARDO-GRANADOS, S. et al. Incidencia de especies de Hemípteros en fresa bajo dos sistemas de cultivo en Irapuato, Guanajuato, México. Southwestern Entomologist, v. 41, n. 2, p. 547
560, 2016. Available from: <http://www.bioone.org.ez67.periodicos. capes.gov.br/doi/abs/10.3958/059.041.0223>. Accessed: Feb. 20, 2017. doi: $10.3958 / 059.041 .0223$.

HADDAD, M. L. et al. Métodos para estimar os limites térmicos e a faixa ótima de desenvolvimento das diferentes fases do ciclo evolutivo dos insetos. Piracicaba: FEALQ, 1999. 29p.

HOFFMAN, R. L.; STEINER JR, W. E. Jadera haematoloma, another insect on its way north (Heteroptera: Rhopalidae). Banisteria, v. 26, p. 7-10, 2005. Available from: <http://www.soapberrybug.org/ dbase_upl/Hoffmann_Steiner_2005.pdf $>$. Accessed: Jun. 10, 2016.

JAROŠÍK, V. et al. Invasive insects differ from non-invasive in their thermal requirements. PLoS ONE, v. 10, n. 6, p. 1-11, 2015. Available from: $<$ http://dx.doi.org/ 10.1371/journal.pone.0131072>. Accessed: Jul. 11, 2016. doi: 10.1371/journal.pone.0131072.

KIRITANI, K. The impact of global warming and land-use change on the pest status of rice and fruit bugs (Heteroptera) in Japan. Global Change Biology, v. 13, 1586-1595, 2007. Available from: <http:// dx.doi.org/10.1111/j.1365-2486.2007.01397.x>. Accessed: Jun. 27, 2016. doi: 10.1111/j.1365-2486.2007.01397.x.

KUHN, T. M. A. et al. Biological parameters and fertility life table of Neopamera bilobata (Hemiptera: Rhyparochromidae) on strawberry. PesquisaAgropecuária Brasileira, v. 49, n. 6,p. 422-427, 2014. Available from: $\quad<$ http://dx.doi.org/10.1590/S0100-204X2014000600003>. Accessed: Jun. 27, 2016. doi: 10.1590/S0100-204X2014000600003.

NORRIS, R. F. et al. Concepts in integrated pest management. Upper Saddle River: NJ. Prentice Hall, 2003. 586 p.

PICKEL, C.; WELCH, N. C.; WALSH, D. B. Timing Lygus sprays using degree-days in Central Coast strawberries. Santa Cruz: Santa Cruz County Agricultural Extension Publication, 1990. 6p.

SPEIGHT, M. R. et al. Ecology of Insects: Concepts and applications. 2. Oxford: Wiley-Blackwell, 2008. 628p.

SILVEIRA NETO, S. et al. Manual de Ecologia dos Insetos. São Paulo: Editora Ceres, 1976. 419p.

TRUDGILL, D. L. et al. Thermal time - concepts and utility. Annals of Applied Biology, v. 146, p. 1-14, 2005. Available from: <http:// dx.doi.org/10.1111/j.1744-7348.2005.04088.x>. Accessed: Jun. 27, 2016. doi: 10.1111/j.1744-7348.2005.04088.x.

UCDAVIS - University of California Agriculture \& Natural Resources. Phenology Model. Database. Online. Available from: $<$ http://www.ipm. ucdavis.edu/PHENOLOGY/ma-lygus_bug.html>. Accessed: Feb. 23, 2015.

WHALEN, R.; HARMON, J.P. Temperature alters the interaction between a herbivore and a resistant host plant. Arthropod-Plant Interactions, v. 9, p. 233-240, 2015. Available from: <http://dx.doi.org/10.1007/s11829015-9366-Z > . Accessed: Jun. 05, 2016. doi: 10.1007/s11829-015-9366-Z.

WILSON, J. W. Notes on Pamera populations on various types of plant communities in the vicinity of Plant City. The Florida Entomologist, v. 21, n. 2, p. 28-30, 1938.

XU, X-M. et al. Development and validation of a model forecasting the phenology of European tarnished plant bug Lygus rugulipennis in the U.K. Agriculture and Forest Entomology, v. 16, n. 3, p. $265-$ 272, 2014. Available from: <http://dx.doi.org/10.1111/afe.12054>. Accessed: Aug. 05, 2017. doi: 10.1111/afe.12054.

Ciência Rural, v.48, n.1, 2018. 